\title{
КАТЕГОРИЈАЛНА ОБЕЛЕЖЈА ИМЕНИЦА У НЕМАЧКОМ И СРПСКОМ ЈЕЗИКУ И ЫИХОВО ПРЕДСТАВЉАЬЕ У ВИШЕЈЕЗИЧНИМ СТРУЧНИМ РЕЧНИЦИМА
}

\begin{abstract}
Предмет овога рада је утврђивање морфолошких карактеристика именица у немачком и српском језику и начина њиховог представљања у вишејезичним стручним речницима објављеним у другој половини двадесетог века. Урађена је анализа именица у немачком и српском језику, без обзира да ли се ови језици налазе у позицији језика изворника или језика циља. Циљ рада је да се утврди у којој мери се морфолошке категорије рода, броја и падежа наводе уз именице у немачком и српском језику у вишејезичним стручним речницима с обзиром на ограниченост простора и компликовано устројство речника овог типа због пратећих регистара који су њихов неизоставан саставни део. Добијени резултати посматрају се у контексту потреба корисника стручних речника који углавном немају филолошко образовање, па је стога присуство граматичких информација уз одредницу веома битно за успешно коришћење речника.
\end{abstract}

Кључне речи: одредница у речнику, именице, немачко-српски стручни речници, вишејезични речници, граматика у речницима, корисници речника

\section{1. Увод}

Предмет овога рада је утврђивање статуса морфолошких категоријалних обележја именица у вишејезичним стручним речницима у којима су заступљени немачки и српски језик. Циљ рада је да се утврди у којој мери се наводе подаци о роду, броју и падежу у речницима овога типа уз именице у немачком и српском језику и да се утврди разлика у морфолошком третману именица са становишта језика изворника и језика циља, узимајући у обзир да ли је речник активни или пасивни.

1 dobbeg@yahoo.de 
У истраживању се пошло од претпоставке да се у стручним речницима, а посебно у вишејезичним стручним речницима не наводи довољно граматичких информација, а ако се оне и наводе, онда се то чини недоследно. Најзаступљенија граматичка информација је род уз именице у немачком језику, али ни то није доследно спроведено. Разлози за то су недостатак простора у вишејезичним речницима објављеним у штампаном облику, али и компетенције аутора који израђује речнике и њихова свест о употребној вредности речника и корисницима којима је намењен, пошто је врло често случај да су речнике радили аутори који су стручњаци за област којој је речник посвећен, а не филолози.

За потребе овога рада урађена је анализа вишејезичних стручних речника објављених у другој половни 20. века у којима су заступљени језички пар немачки и српски како би се дошло до закључка о заступљености граматичких података уз именице у немачком и српском језику. Приликом анализе вршено је поређење ових категорија у немачком и српском језику и изведени су закључци о њиховој заступљености. На крају су коришћењем статистичких параметара дати подаци о заступљености истраживаних категорија.

\section{2. Граматички подаци у стручним речницима}

Навођење граматичких података у речницима питање је које свакодневно заокупља лексикографе који се баве практичном лексикографијом. За лексикографа, а касније и за корисника изузетно је битно питање укључивања морфолошких информација у речник и начина њиховог презентовања. Са тим проблемом лексикограф се сусреће одмах након што је саставио листу одредница у фази кад треба да унесе све потребне информације, објашњења, податке и коментаре (HAS-CUMKER 2001: 24). Питање граматике у речницима оптерећује лексикографа у истој мери као и семантизација и представља једно од централних питања на која одговор треба да да̂ металексикографија као научна дисциплина која се бави теоретским истраживањима речника (VIGAND 1989: 257), а посебно статусно-употребна металексикографија која се бави изучавањем друштвеног статуса и употребе речника (ŠIPKA 2006: 160). Ако се посматрају језички пар немачки и српски постоји велика несразмера између теоријске или металексикографије и практичне лексикографије која се бави израдом речника, посебно у области стручне лексикографије. Практична лексикографија доста је развијенија, израда речника има дугу традицију, док бројни феномени који спадају у домен теоријске лексикографије још нису истражени.

Граматичке категорије у вишејезичној стручној лексикографији у којој су заступљени немачки и српски (српскохрватски) језик до сада 
нису биле предмет истраживања. Стручном лексикографијом језичког пара немачки и српски бави се делимично рад Nemačko-srpsko-hrvatska leksikografija prve polovine XX veka (PETRONIJEVIĆ 2002). Стручним речницима у овом раду посвећено је мало пажње, сразмерно малом броју стручних речника који су објављени у овом периоду. У периоду од 1900. до 1944. године објављено је укупно 107 речника од чега шеснаест посебне намене који представљају зачетке стручних речника. Од тога је само шест тројезичних који се могу сматрати вишејезичним речницима. Стручном лексикографијом језичког пара немачки и српски бави се и рад Домети стручне лексикографије немачког и српског језика (BEGENIŠIĆ 2016). У овом раду урађена је библиографија стручних речника у којима су заступљени немачки и српски језик, као и анализа речника са становишта лексикографско-лексиколошког поступка, стручне припадности, типологије, поделе по смеру, броју заступљених језика, социолингвистичком контексту. Проблем недовољног истраживања вишејезичне стручне лексикографије спознао је Понтен још 1976. године. Понтен износи мишљење да би вишејезичној лексикографији требало посветити много више пажње у оквиру лингвистике и да би она, због значаја и комплексности, требало да буде предмет проучавања самосталне научне дисциплине, како теоретске тако и практичне (PONTEN 1976).

Циљ овога рада је да се утврди лексикографски поступак у вишејезичним стручним речницима и то пре свега у домену третмана именица као најзаступљеније врсте речи у стручним речницима уопште. Резултати истраживања представљају битан показатељ за даљи рад на стручним речницима посебно у области израде речника, а нарочито ако се у обзир узму савремени трендови у лексикографији где је све заступљенија електронска лексикографија, која омогућава да се у речник унесу све потребне информације, пошто у електронској лексикографији неки проблеми који су пратили традиционалну лексикографију нестају (питање простора, економичност и сл.).

\section{3. Именице у немачком и српском језику}

И у немачком и српском језику именице су променљива врста речи коју карактеришу категоријална обележја рода, броја и падежа. Ипак, приликом поређења именица у немачком и српском језику уочљиве су битне разлике. У морфолошком погледу именице у српском језику показују већу самосталност него именице у немачком језику. У српском су саме именице носиоци ознака за падеж, род и број, док код немачких именица род број и падеж маркирају њихови пратиоци: детерминативи и придеви који су задржали флексију или се те категорије препознају по предлогу или положају у реченици. 
Укључивање морфолошких информација у речник битно је нарочито код језика са развијеном морфологијом, а карактер и количина тих информација повезани су са наменом речника, те са типологијом и обимом. При навођењу именица у речницима у немачком језику наводе се по правилу род (мушки, женски, средњи), наставак за генитив једнине и номинатив множине. У српском језику уз именице се обично наводи род, а неки други подаци наводе се само у случају да именица у некој категорији одступа од правила.

\section{4. Анализа корпуса}

Истраживање је спроведено на корпусу немачко-српских (српскохрватских) и српско (српскохрватско)-немачких вишејезичних стручних речника објављених у периоду од 1945. до 2000. године у Србији. У корпус за анализу укључени су и речници са више места издања уколико је једно од места било у Србији. У истраживаном периоду објављено је 36 речника у 48 издања. Вишејезичним речницима сматрали смо речнике у којима је заступљено три и више језика. Посматрано према броју заступљених језика, у овом периоду објављено је шест тројезичних, четрнаест четворојезичних, седам петојезичних, четири шестојезична, тринаест седмојезичних, један осмојезични и три деветојезична речника. У анализираним речницима заступљена је терминологија из медицине, спорта, угоститељства и гастрономије, пољопривреде, политичког и друштвеног система, технике, металургије, војне индустрије, економије, права и финансија, свих грана индустрије и привреде, музике, позоришта, математике, штампарства и издаваштва. За потребе ове анализе сви речници су прегледани и анализиран је статус именица у њима.

Први стручни речник у овом периоду објављен је 1954. године у Београду (VUKOV 1954), а последњи 2000. године такође у Београду (ŠIJAK 2000).

У датом корпусу анализирали смо граматичке категорије род, број и падеж уз именице у немачком и српском језику без обзира да ли су ти језици полазни тј. да ли имају статус језика изворника (ЈИ) или језика циља (ЈЦ). Од укупног броја вишејезичних стручних речника српски је ЈИ у осам речника, српскохрватски у двадесет, српскохрватски/хрватски или српски у једном, а српскохрватски/хрватскосрпски у два речника, немачки је ЈИ у два речника, а у осталим речницима језик изворник је неки други страни језик (у шест енглески, у једном француски, у пет латински, у једном руски). У свим овим речницима где је ЈИ неки други страни језик српски и немачки спадају у групу језика који су Ј.

Посебно треба посматрати два тројезична речника (RADIVOJEVIĆ 1993; ŽIVOJINOVIĆ-JAPANAC 1998) која се састоје од 
по три тројезична речника, тако да језик изворник варира. Речник за текстил и кожу (RADIVOJEVIĆ 1993) садржи енглеско-немачко-српски, немачко-енглеско-српски, српско-енглеско-немачки речник, а Речник штампарства и издаваштва (ŽIVOJINOVIĆ-JAPANAC 1998) садржи немачко-српско-енглески, енглеско-српско-немачки и српско-немачкоенглески речник, тако да се немачки и српски у оба речника појављују и као ЈИ и као ЈЦ.

У спроведеном истраживању сматраћемо да се наводе категоријална обележја именица уколико су наведени подаци о роду, облику за генитив једнине и номинатив множине уз именице у немачком језику било да је он ЈИ или ЈЦ. Анализираћемо такође да ли је и на који начин наведен податак о роду за именице у српском језику, такође са становишта ЈИ и Ц. Приликом анализе посматрали смо на који начин су маркирана та обележја.

Род је морфолошка категорија која је својствена именицама и у српском и у немачком језику. Увидом у речнике могуће је констатовати да се категорија рода не бележи у двадесет речника ни у ЈИ нити у ЈЦ (ABDULI i dr. 1983; 1985; AVERBAH 1980; 1988; BANIĆEVIĆ, POPOVIĆ i dr. 1989; 1990; ĐORĐEVIĆ i dr. 1966; 1975; GAKOVIĆ, BOŽIĆ 1971; HRISTOVSKI 1994; JOVANOVIĆ 1965; KOSTIĆ 1956; 1971; 1976; 1987; 1996; PETRANOVIĆ 1991; RAŠOVIĆ 1991; ŠIJAK 2000; VUKOV 1954).

У свим овим речницима немачки има статус ЈЦ, а српски је ЈИ у тринаест речника, а у седам речника ЈИ је неки други страни језик (у два енглески, у пет латински), а српски спада у групу језика који су ЈЦ. Нпр.

$\begin{array}{ll}\text { 05-01-085 } & \\ \text { Srpskohrvatski } & \text { - Linije polja; linije sila } \\ \text { Francuski } & \text { - Ligne de champ; ligne de force } \\ \text { Engleski } & \text { - Line of force } \\ \text { Nemački } & \text { - Feldlinie; Kraftlinie } \\ \text { (RAŠOVIĆ 1991: 17) } & \end{array}$

English

1. Accept v

2. Adjourn $v$

a) adjourned game

b) adjourned position

(AVERBAH 1980: 20)
Deutsch

annehmen

abbrechen

Hängepartie

abgebrochene

Partie

Hängestellung

Abbruchstellung
Srpskohrvatski

prihvatiti

prekinuti

prekinuta partije

prekinuta pozicija 
Најзаступљенија граматичка категорија у речницима је обележавање рода уз именице у немачком и/или српском језику. Род је обележен у 28 од укупно 48 речника. Род се маркира навођењем латинске ознаке $m$, $f, n$ испред или иза именице.

У речницима у којима је обележен род заступљене су различите варијанте: род се маркира у оба језика било да ти језици имају статус ЈИ или ЈЦ, род се маркира само у ЈИ, род се маркира само у Ц, а могуће су и друге комбинације које ће у даљем тексту бити представљене.

Маркирање рода у оба језика без обзира да ли ови језици имају статус ЈИ или ЈЦ присутно је у тринаест речника од којих је у два немачки JИ (BAJIĆ, DUNĐEROVIĆ i dr. 1973; MEKIĆ 1991), а српски (српскохрватски, српскохрватски/хрватски или српски, српскохрватски/хрватскосрпски) у десет (С̌OBIĆ 1994; 1996; POPOVIĆ 1981; RISTIĆ, OBRADOVIĆ i dr. 1961; 1964; 1971; TEHNIČKI REČNIK ZA BRANE 1965; JANKOVIĆ, ĐUROVIĆ i dr. 1969, JOVANOVIĆ 1959; STEFANOVIĆ 1980). Нпр.

\section{Deutsch}

82 Abnahme (f)

83 Abnahmeleiste (f) letva (f) za skidanje

84 Abnahmewalze (f) valjak (m) za skidanje

98 abquetschen cediti

(MEKIĆ 1991: 9)

\section{Srpskohrvatski}

smanjenje (n)

\section{English}

reduction

take off rail

take off roller

squeeze; nip; mangle

\section{3. ananas $m$.}

L. Ananas sativud, fam. Bromeliacea

E. pinaepple

F. ananas $m$.

D. Ananas $f$.

ES piña F. ananás $m$.

P. ананас $m$.

(ČOBIĆ 1994: 7)

У једном речнику немачки и српски појављују се и као ЈИ и као ЈЦ (ŽIVOJINOVIĆ-JAPANAC 1998) где се у немачком без обзира да ли је ЈИ или ЈЦ доследно наводи род, а у српском недоследно без обзира да ли је ЈИ или ЈЦ. Нпр.
Abtastung $f$
skeniranje $n$
scanning
Abweichung $f$
odstupanje $n$, devijacija $f$
deviation (process)
Abziehlack $m$
lak za otiskivanje
Achsel $f$ rame $n$ (deo slova)
(ŽIVOJINOVIĆ-JAPANAC 1998: 5)
stripping varnish (retouching)
shoulder (part of the letter) 
agens za sušenje $m \quad$ Trockenstoff $m \quad$ drying agent (ink additive) siccative (ink additive)

ahromatska boja $f$ unbunte Farbe $f$ achromatic colour akcidentični slog $m$ Akzidenzsatz $m$ digester (papermaking) (ŽIVOJINOVIĆ-JAPANAC 1998: 417)

Што се тиче осталих речника српски је ЈИ у још осам (JOVIĆ 1995; MILOJEVIĆ 1996; NEŠIĆ 1970; PEJOVIĆ 1966; PERIČIĆ 1985; 1997; RADOVČIĆ 1966; TOT 1975). Ни у једном од њих нису наведени никакви подаци уз именице у српском језику док су у свим овим речницима наведени подаци о раду уз именице у немачком као језику који има статус ЈЦ. Нпр.

\section{A-60}

актинијум

e. actinium

H. Aktinium $n$

ф. actinium $m$

p. актиний

(JOVIĆ 1995: 7)

У преосталих шест речника ЈИ је неки други страни језик (енглески, француски, руски) (KNEŽEVIĆ 1996; KOSTIĆ, KOSTIĆ 1991; 1995; KOVENSKI 1980; MUŠKATIROVIĆ, MOJSILOVIĆ 1992; REJ 1997), а немачки и српски имају статус језика циља. У свим овим речницима наведен је податак о роду уз именице у немачком као ЈЦ, а само у једном уз именице у српском језику као ЈЦ (KOVENSKI 1980).

$\begin{array}{llll}\text { accessories } & \text { accessoires } p l & \text { Zubehör } n & \text { oprema; pribor } \\ \text { accretion } & \text { accroissement } m & \begin{array}{l}\text { Zuwachs } m, \quad \text { priraštaj; porast } \\ \text { Vergrößerung } f\end{array}\end{array}$

(KOSTIĆ-KOSTIĆ 1995: 4)

А8 агломерат $m$

E. agglomerate

D. Agglomerat $n$

Gesinter $n$

F aggloméré $m$

Agglomérat $m$

$S$ aglomerat $m$

(KOVENSKI 1980: 1) 
Као изузетак треба навести Речник за текстил и кожу (RADIVOJEVIĆ 1993) који се састоји од три тројезична речника: енглеско-немачко-српски, немачко-енглеско-српски, српско-енглеско-немачки. У овом речнику и немачки и српски се појављују и као ЈИ и као ЈЦ. Уз именице у немачком језику увек је наведено обележје рода, без обзира да ли је немачки у позицији ЈИ или ЈЦ. У српском ово обележје није наведено ни у ЈИ ни у Ј.

Abrasion $s$ / Abrieb $m$, Scheuern $n$ Abscheuerung f / abrazija, trenje, nagrizanje (RADIVOJEVIĆ 1993: 3)

abrazija, trenje /Abrasion $s$ / Abrieb $m$, Scheuern $n$ (RADIVOJEVIĆ 1993: 419)

Што се тиче осталих категорија уз именице, а пре свега наставка за генитив једнине и номинатив множине уз именице у немачком језику, ти подаци су наведени само у једном речнику који је у овом периоду изашао у два издања (PERIČIĆ 1985; 1997). У том речнику наведен је податак за номинатив множине именица у немачком језику, али веома недоследно. Тај податак је наведен само уколико се музички термин уобичајено користи у множини. У том случају није дат облик именице у номинативу једнине. Нпр.

37. akordski instrumenti (i. na kojima se može svirati višeglasno)

I strumenti $m p l$ polifonici

F instruments $m p l$ polyphoniques

N Akkordinstrumente $n p l$

$\mathrm{R}$ инструменты $m p l$

Ч akordické nástroje $m p l$

(PERIČIĆ 1997: 17)]

\section{5. Закључак}

Анализа именица у вишејезичним стручним речницима у којима су заступљени немачки и српски језик показала је да се граматички подаци уз именице наводе у 28 од укупно 48 речника (58\%). У свим речницима у којима се наводе граматички подаци, наведен је податак о роду именица у немачком језику, било да је он ЈИ (два речника) или ЈЦ (24 речника) и у два речника где се немачки појављује и у позицији ЈИ и ЈЦ (ŽIVOJINOVIĆ-JAPANAC 1998; RADIVOJEVIĆ 1993). За маркирање рода коришћене су уобичајене латинске скраћени $(m, f, n, p l)$.

Што се тиче именица у српском језику, род је наведен у десет речника где је српски ЈИ, у једном речнику где се српски појављује као ЈИ 
и као ЈЦ (ŽIVOJINOVIĆ-JAPANAC 1998) и у једном речнику где је српски Ј (KOVENSKI 1980), што износи 25\% од укупног броја речника.

Од укупно објављених 48 речника српски (српскохрватски) је ЈИ у 31 речнику, немачки у два, неки други страни језик у 13, а немачки, српски и енглески имају статус ЈИ и Ј у два речника због тога што се та два речника састоје заправо од по три тројезична речника.

Од осталих граматичких података уз именице, само у једном речнику наведен је облик за множину именица у немачком језику, али и то недоследно (2\%). Остали граматички подаци нису заступљени ни у једном речнику.

На основу добијених резултата може се закључити да се граматички подаци уз именице у вишејезичним стручним речницима не наводе у скоро половини издања. Ти подаци се наводе знатно чешће уз именице у немачком језику него уз именице у српском језику. Најдоследније се наводи граматичка категорија рода уз именице у немачком језику. Али и тај податак налазимо у нешто више од половине објављених речника. Анализа корпуса показала је да морфолошке информације у стручним речницима нису честа појава и да немају примарни значај те да не постоје јединствени критеријуми за њихово навођење у вишејезичним стручним речницима као и да у њима није заступљен граматички минимум. Минимум граматичких података које би требало навести уз именице у немачком језику представља обележавање рода, навођење наставка за генитив једнине и номинатив множине. Уз именице у српском језику оптимално би било да се обележи род и у неким случајевима облик за генитив једнине и номинатив множине.

Принцип неусаглашености по питању уноса граматичких података у речник присутан је у целокупној преводној лексикографији. Ипак, овај проблем највише је изражен у вишејезичним стручним речницима. Разлог за то је недостатак простора у штампаним издањима, а то обично иде на штету граматичких података. Разлоге треба тражити и у компетенцијама њихових аутора, пошто они углавном немају филолошко образовање него су стручњаци за област којој је речник посвећен. На успелијим лексикографским издањима радили су тимови стручњака, међу њима и филолози који имају комплексно образовање за језик који је заступљен. Тај тимски рад обично се одразио на квалитет речника у позитивном смислу, пошто је за израду квалитетног речника подједнако важно познавање одређене струке и поседовање филолошког образовања.

Анализа је показала да постоји велика потреба за даљим истраживањем вишејезичне стручне лексикографије у којој је заступљен језички пар немачки и српски као и примене добијених резултата у будућој лексикографској пракси. Будућност израде речника лежи у електронској 
лексикографији, пошто нови носиоци информација омогућавају поштовање и примену принципа савремене лексикографије у пуном обиму. У електронској лексикографији нестају неки од кључних проблема класичне лексикографије као што је недостатак простора за навођење додатних информација чиме се отварају нове могућности за организацију и презентовање грађе. У речнике у електронској форми могуће је уношење већег броја података него што је то случај са речницима у класичној штампаној форми и зато у изради речника у будућности треба дати предност електронским носиоцима информација, како би они били боље прилагођени кориснику и омогућили бржу доступност тражених информација.

\section{Цитирана литература}

BEGENIŠIĆ 2016: BEGENIŠIĆ, Dobrila. Dometi stručne leksikografije nemačkog $i$ srpskog jezika. Beograd: Miroslav, 2016. [orig.] БЕГЕНИШИЋ, Добрила. Домети стручне лексикографије немачког и српског језика. Београд: Мирослав, 2016.

VIGAND 1989: Wiegand, H. E. „Der gegenwärtige Status der Lexikographie und ihr Verhältnis zu anderen Disziplinen". Handbücher zur Sprach- und Kommunikationwissenschaft. Berlin: de Geuyter, 1989: 246-280.

PETRONIJEVIĆ 2002: PETRONIJEVIĆ, Božinka. Nemačko-srpsko-hrvatska leksikografija. Beograd: Filološki fakultet, 2002

PONETEN 1976: Ponten, J. „Das Übersetzungswörterbuch und seine linguistischen Implikationen".

Probleme der Lexikologie und Lexikographie. Düsseldorf: Schwan, 1976: 200-210.

HAS-CUMKER 2001: HAß-ZUMKEHR, Ulrike. Deutsche Wörterbücher -Brennpunkt von Sprach-und Kulturgeschichte. Berlin: de Guyter, 2001.

ŠIPKA 2006: ŠIPKA, Danko. Osnovi leksikologije i srodnih disciplina. Novi Sad: Matica srpska, 2009.

\section{Kopnyc}

ABDULI i dr. 1983: ABDULI, Ramiz i dr. Terminološki rečnik iz operacionih istraživanja. Beograd: Fakultet organizacionih nauka, 1983.

ABDULI i dr. 1985: ABDULI, Ramiz i dr. Terminološki rečnik iz operacionih istraživanja. Beograd: Naučna knjiga, 1985.

AVERBAH 1980: AVERBAH, Jurij. Mali šahovski rečnik. Beograd: Šahovski informator, 1980.

AVERBAH 1988: AVERBAH, Jurij. Mali šahovski rečnik. Beograd: Šahovski informator, 1988.

BAJIĆ, DUNĐEROVIĆ i dr. 1973: BAJIĆ, Branislav i Aleksandar DUNĐEROVIĆ, Nikola KERN. 
Poslovni privredno-tehnički rečnik. Beograd: Privredni pregled, 1973.

BANIĆEVIĆ, POPOVIĆ i dr. 1989: BANIĆEVIĆ, Marta i Magdalena POPOVIĆ, Jelena VULOVIĆ.

Ugostiteljski rečnik. Beograd: Naučna knjiga, 1989.

BANIĆEVIĆ, POPOVIĆ i dr. 1990: BANIĆEVIĆ, Marta i Magdalena POPOVIĆ, Jelena VULOVIĆ. Ugostiteljski rečnik. Beograd: Naučna knjiga, 1990.

VUKOV 1954: VUKOV, Lazar. Imenik jela i pića. Beograd: Zadruga, 1954.

GAKOVIĆ, BOŽIĆ 1971: GAKOVIĆ, Nikola i Branko BOŽIĆ. Metalurški rečnik. Beograd: Građevinska knjiga, 1971.

ĐORĐEVIĆ i dr. 1966: ĐORĐEVIĆ, Jovan i dr. Mala politička enciklopedija. Beograd: Savremena administracija, 1966.

ĐORĐEVIĆ i dr. 1975: ĐORĐEVIĆ, Jovan i dr. Politička enciklopedija. Beograd: Savremena administracija, 1975.

ŽIVOJINOVIĆ-JAPANAC 1998: ŽIVOJINOVIĆ-JAPANAC, Dragoljub. Rečnik štamparstva i izdavaštva. Beograd: Udruženje naučnih i stručnih prevodilaca Srbije, 1998.

JANKOVIĆ, ĐUROVIĆ i dr. 1969: JANKOVIĆ, Margita i Radomir ĐUROVIĆ, Radosav JANKOVIĆ. Ekonomsko-pravni rečnik. Beograd: Međunarodna politika, 1969.

JOVANOVIĆ 1959: JOVANOVIĆ, Aleksandar. Srpskohrvatsko-englesko-nemačkofrancuski rečnikprivrednih, komercijalnih, finansijskih, političkih i pravnih izraza. Beograd: Savremena administracija, 1959.

JOVANOVIĆ 1965: JOVANOVIĆ, Toma. Elektrotehnički terminološki rečnik. Beograd: Tehnička knjiga, 1965.

JOVIĆ 1995: JOVIĆ, Vidojko. Geohemijski rečnik. Beograd: Savremena administracija, 1995. [orig.]

ЈОВИЋ, Видојко. Геохемијски речник. Београд: Савремена администрација, 1995.

KNEŽEVIĆ1996: KNEŽEVIĆ, Jasmina. Rečnik železničkih stručnih izraza. Beograd: Želnid, 1996.

KOVENSKI 1980: КОВЕНСКИ, И. И. и др. Петојезични речник термина металургије праха.

Београд: Завод за графичку технику Технолошко-металуршког факултета, 1980.

KOSTIĆ 1956: KOSTIĆ, Aleksandar Đ. Medicinski rečnik. Beograd, Zagreb: Medicinska knjiga, 1956.

KOSTIĆ 1971: KOSTIĆ, Aleksandar Đ. Višjezički medicinski rečnik. Beograd: Medicinska knjiga, 1971.

KOSTIĆ 1976: KOSTIĆ, Aleksandar Đ. Višjezički medicinski rečnik. Beograd: Institut za stručno usavršavanje i specijalizaciju zdravstvenih radnika, 1976. 
KOSTIĆ 1987: KOSTIĆ, Aleksandar Đ. Višjezički medicinski rečnik. Beograd: Nolit, 1987.

KOSTIĆ 1996: KOSTIĆ, Aleksandar Đ. Višjezički medicinski rečnik. Beograd: Savremena administracija, 1996.

KOSTIĆ, KOSTIĆ 1991: KOSTIĆ, Veljko i Ljiljana KOSTIĆ. Tehnološki rečnik. Beograd: Privredni pregled, 1991.

KOSTIĆ, KOSTIĆ1995: KOSTIĆ, Veljko i Ljiljana KOSTIĆ. Tehnološki rečnik. Beograd: Grmeč-Privredni pregled, 1995.

MEKIĆ 1991: MEKIĆ, Rahel. Trojezični rečnik sa terminologijom iz tekstilne tehnologije. Novi Sad: Prometej, 1991.

MILOJEVIĆ 1996: MILOJEVIĆ, Dobrivoje. Leksikon finansijskih tržišta. Beograd: Savremena Administracija. 1996.

MUŠKATOROVIĆ, MOJSILOVIĆ 1992: MUŠKATIROVIĆ, Milica i Radojka MOJSILOVIĆ. Rečnik pivarskih termina. Beograd: Jugoslovensko udruženje pivara, 1992.

NEŠIĆ 1970: NEŠIĆ, Gojko. Rudarski rečnik. Beograd: Rudarski institut, 1970.

PEJOVIĆ 1966: ПЕЈОВИЋ, Тадија. Речник математичких термина. Београд: Завод за уџбенике Социјалистичке републике Србије, 1966.

PERIČIĆ 1985: ПЕРИЧИЋ, Властимир. Вишејезични речник музичких термина. Београд: САНУ,

1985.

PERIČIĆ 1997: ПЕРИЧИЋ, Властимир. Вишејезични речник музичких термина. Београд: САНУ, 1997.

PETRANOVIĆ 1991: PETRANOVĆ, Josip. Višejezični pravno-ekonomski rečnik. Beograd: Udruženje naučnih i stručnih prevodilaca Srbije, 1991.

POPOVIĆ 1981: POPOVIĆ, Mladen. Rečnik iz grejanja, hlađenja i klimatizacije. Beograd: Savez mašinskih i elektrotehničkih inženjera i tehničara Srbije, 1981.

RADOVČIĆ 1966: RADOVČIĆ, Ante. Rečnik šumarskih izraza. Beograd: Šumarstvo,

Organ Saveza inženjera i tehničara šumarstva i drvne industrije SR Srbije, 1966.

REJ 1997: REJ, Kenet. Internacionalni rečnik pozorišnih termina. Beograd: Gea, 1997. RISTIĆ, OBRADOVIĆ i dr. 1961: RISTIĆ, Svetomir i Nikola OBRADOVIĆ, Pavle VASIĆ. Rečnik tehničkih izraza. Beograd: Tehnička knjiga, 1961.

RISTIĆ, OBRADOVIĆ i dr. 1964: RISTIĆ, Svetomir i Nikola OBRADOVIĆ, Pavle VASIĆ. Rečnik tehničkih izraza. Beograd: Tehnička knjiga, 1964.

RISTIĆ, OBRADOVIĆ i dr. 1971: RISTIĆ, Svetomir i Nikola OBRADOVIĆ, Pavle VASIĆ. Rečnik

tehničkih izraza. Beograd: Tehnička knjiga, 1971.

RADIVOJEVIĆ 1993: RADIVOJEVIĆ, Mirjana. Rečnik za tekstil $i$ kožu. Beograd: Sa- 
vremena administracija, 1993.

RAŠOVIĆ 1991: RAŠOVIĆ, Miljan. Pojmovnik rečnik elektrotehnike. Beograd: Sfairos, 1991.

STEFANOVIĆ 1980: STEFANOVIĆ, Milutin. Višejezični geodetski rečnik. Beograd: Savez geodetskih inženjera i geometara Jugoslavije, 1980.

TEHNIČKI REČNIK ZA BRANE 1965: Tehnički rečnik za brane, Beograd: Građevinska knjiga, 1965.

TOT 1975: TOT, Rudolf. Terminološki komparativni srpskohrvatsko-nemačko-englesko-mađarski rečnik iz kibernetske informatike. Subotica: Ekonomski fakultet, 1975.

HRISTOVSKI 1994: HRISTOVSKI, Metodija. Eksplozivne materije. Beograd: Vojska, 1994.

ČOBIĆ 1994: ČOBIĆ, Timotej. Višejezički rečnik voća, povrća i začina. Beograd: Prosveta, 1994.

ČOBIĆ 1996: ČOBIĆ, Timotej. Višejezički rečnik poljoprivredne mehanizacije. Novi Sad: Poljoprivredni

Fakultet, 1994.

ŠIJAK 2000: ŠIJAK, Milorad. Višejezični dendrološki rečnik. Beograd: Šumarski fakultet, 2000. 
Dobrila Begenišić

\section{KATEGORIALE MERKMALE DER SUBSTANTIVE IN DER DEUTSCHEN UND SERBISCHEN SRPACHE UND IHRE MARKIERUNG IN DEN MEHSRPACHIGEN FACHWÖRTERBÜCHERN}

In dieser Arbeit wurden die morphologischen Merkmale der Substantive und Art und Weise ihrer Markierung in den mehrsprachigen Fachwörterbüchern der serbischen und deutschen Sprache analysiert. Als Grundlage für diese Forschung dienten mehsprachige Fachwörterbücher der serbischen und deutschen Sprache, die in der zweiten Hälfte des 20. Jahrhunderts in Serbien veröffentlicht worden sind. Es wurden grammatische Kategorien Genus, Numerus und Kasus in Betracht gezogen. Wir sind aber zu einer Schlußfolgerung gekommen, dass die zur Analyse herangezogenen Wörterbücher viele Mängel, Verschiedenheiten und Wiedersprüchlichkeiten hinsichtlich der Markierung der morphologischen Merkmale der Substantive zeigen.

Ein allgemein angenommenes Kriterium darüber, welche grammatische Angaben ein gutes mehrsprachiges Fachwörterbüch enthalten sollte und auf welche Weise sie präsentiert werden sollten, besteht noch nicht. Morphologische Bezeichnungen sollten in dem Maß eingetragen werden, in dem sie zu einem vollständigeren Gebrauch der in einem Wörterbüch enthaltenen Wörter dienen. Ein gewisses grammatisches Minimum, das jedes Wörterbuch enthalten sollte, muss angeführt werden, weil im Gegenteil die meisten Wörterbücher in einer konkreten Situation nicht erflogreich benutzt werden könnten.

Schlüsselwörter: Bestimmungswort im Wörterbuch, Substantive, deutsch-serbische Fachwörterbücher, mehrsprachige Wörterbücher, Grammatik im Wörterbüch, Benutzer der Wörterbücher 